\title{
Біотехнологія пшениці. Нові підходи до оцінювання морозистій- кості генотипів пшениці озимої
}

\section{Лариса Сергсєва, Лідія Хоменко, Лариса Броннікова}

Інститут фізіології рослин і генетики НАН України, Київ, Україна

Адреса для листування: zlenko_lora@ukr.net

Отримано: 22.09.18; прийнято до друку: 26.10.18; опубліковано: 26.12.18

\begin{abstract}
Резюме. Оцінювали морозостійкість генотипів пшениці озимої. Морозостійкість - це комплексна характеристика цілісного організму. Під час ії оцінки застосовують такий біотехнологічний прийом, як проморожування. При цьому поза увагою залишаються пов'язані зі стійкістю реакції клітинного рівня. Водночас клітинні культури, що відзначаються підвищеним рівнем стійкості, є об'єктами масштабних досліджень. Пропонується новий підхід до оцінювання морозостійкості пшениці озимої, який поєднує методи дослідження in vivo та in vitro.

Генотипи пшениці озимої піддавали процедурі загартування/проморожування на стадії накільчених зернівок in vivo, а потім вирощували в польових умовах. Зміни умов впливу здійснювали в декілька етапів: 1) зниження температури від $0^{0} \mathrm{C}$ до $-8^{0} \mathrm{C}\left(2^{0} / 48\right.$ год); 2) зниження температури від $-8^{0} \mathrm{C}$ до $-20^{0} \mathrm{C}$ $\left(2^{0} \mathrm{C} /\right.$ год $\left.) ; 3\right)$ проморожування при $-20^{0} \mathrm{C}$ упродовж 24 год. Із регенерованих рослин виділяли незрілі зародки, отримували клітинні культури та оцінювали ступінь життєздатності тканин інтактної рослини за характером реакцій культур in vitro на різних культуральних середовищах. Відзначено різні типи реакції, залежних від генотипу й середовища: пряме проростання, калусогенез, комбінування обох типів. Найбільш показовою виявилася реакція прямого проростання.

Установлено, що генотипи пшениці озимої суттєво різняться за рівнем морозостійкості. Показано, що поєднання методів in vivo та in vitro створює можливість ранжування генотипів пшениці озимої за рівнем морозостійкості.
\end{abstract}

Ключові слова: пшениця озима, загартування/проморожування in vivo, клітинні культури in vitro, морозостійкість.

\section{There is the Wheat Biotechnology. New Approaches of Evaluation of Fall Wheat Frost Resistance}

\section{Larisa Sergeeva, Lidia Khomenko, Larisa Bronnikova}

Institute of Plant Physiology and Genetics, National Academy of Scienses of Ukraine, Kyiv, Ukraine Correspondence: zlenko_lora@ukr.net

\footnotetext{
Abstract. The frost resistance of the fall wheat genotypes was evaluated. The frost resistance is the integrated characteristic of entire plant. Freezing procedure is one of the biotechnological approaches of its investigation. But during this procedure a lot of functions connected with stress resistance that realized on cellular level remain unknown. On the other hand genetic and physiological characteristics of cell cultures are successfully studied. The combination of the in vivo and in vitro approaches is proposed for estimation the wheat frost resistance.

Grains on initial stage of shooting were passed through hardening/freezing procedures. The hardening protocol declares: the temperature lowering from $0^{0} \mathrm{C}$ to $-8^{0} \mathrm{C}$ with step $2^{0}$ per 48 hours; then subsequent temperature was decreased from $-8^{0} \mathrm{C}$ to $-20^{0} \mathrm{C}$ with step $2^{0}$ per hour. After this manipulation grains were maintained under $-20^{\circ} \mathrm{C}$ temperature stress during 24 hours and sowed into the soil.
} 
From recovered plants immature embryos were dissected and transferred to a number of nutritional media. Cell cultures were induced from these explants. Various genotype-depended and medium-depended reactions of cultures were marked. They are: simple germination, calli induction, the combination of both processes. The freezing process decreased the number of survived plants. The most adequate expression of tissues viability was the reaction of simple germination.

It was shown that fall wheat genotypes frost resistance essentially vary. Procedures of in vivo young grain shoots freezing replaced by the detection of cell cultures viability are the appropriate biotechnology for the selection of wheat frost resisted variants.

Key words: fall wheat, hardening/freezing in vivo, cell cultures in vitro, frost resistance.

\section{Вступ}

Отримання генетично змінених форм рослин підпорядковується відпрацьованому алгоритму, а отже, є біологічною технологією. При цьому, зазвичай, розрізняють два напрями: традиційний, котрий передбачає маніпуляції 3 інтактною рослиною in vivo, та альтернативний, здебільшого пов'язаний із системою in vitro.

3 огляду на кардинальні зміни клімату одержання генотипів, стійких до абіотичних стресів, є пріоритетною метою. Зрозуміло, що досягнення успіху можливе за умов адекватного оцінювання стресового навантаження та характеру викликаних ним змін у рослині.

Значними успіхами відзначено дослідження проблеми стійкості до осмотичних стресів (засолення, водний дефіцит). У межах цієї проблеми формуються напрями, пов'язані 3 конкретними фізіолого-біохімічними показниками життєдіяльності, що гарантовано вказують на генетично зумовлені особливості [1]. Цьому сприяє тотожність маніпуляцій iз рослинною та клітинною культурою, отриманою із неї; можливість моделювати природні стреси в системі in vitro.

Складніші справи 3 дослідженням стійкості пшениці озимої до низьких температур. Ця ознака асоційована 3 реалізацією процесів на рівні тканин і клітин. Водночас установити рівень морозостійкості та виділити стійкі генотипи можливо лише після прямої стресової дії на інтактну рослину, що коректно проводиться виключно in vivo. При цьому ступінь патологічних змін (у природі) можна оцінити під час відновлення рослини через значний проміжок часу. Відростання відбувається за рахунок життєздатних паренхіматичних (недиференційованих) клітин. A ймовірна присутність/вплив віддалених наслідків від'ємних температур узагалі лишається поза межами вивчення.

Отже, дослідження морозостійкості на різних ієрархічних рівнях in vivo й in vitro $€$ викликом часу.

Паралельні дослідження морозостійкості in vivo та in vitro проводили в Миронівському інституті пшениці ім. В. М. Ремесла [2]. Так, В. С. Гірко, (2007), із використанням модельного сортименту генотипів пшениці озимої Миронівська 808, Кінельська 4, Кошутка, Рання 12 отримав та здійснював проморожування калусних культур у температурному діапазоні $-8^{0}:-24^{0} \mathrm{C}$. Установлено, що $\mathrm{t}^{0}-8^{0}$ спричиняла зменшення приросту біомаси культури, не пригнічуючи регенераційної здатності. Оптимальною температурою для проведення добору була $\mathrm{t}^{0}$ $12^{0} \mathrm{C}, \mathrm{t}^{0}-16^{0} \mathrm{C}$ виявилася летальною для більшості калусних культур. Незважаючи на отримані результати, диференціювати генотипи за ознакою морозостійкості не вдалося 3 декількох причин. По-перше, система in vitro перешкоджає прямому контакту клітин із холодним повітрям. По-друге, теплоємність полісахариду (агару) суттєво знижує стресове навантаження. По-третє, якісний склад живильного середовища підтримує життєздатність культури. У результаті простежено незбереження ознаки в поколіннях. $\mathrm{He}$ заперечуючи можливості добору форм із гібридних популяцій, автори вказують на негарантованість цієї події. Зазвичай оцінку пшениці озимої на морозостійкість - основну складову ознаку зимостійкості - пов'язували 3 різноманітними способами проморожування [3]. Найбільш достовірну оцінку стійкості об'єкта до низьких температур надають польові дослідження, а саме: візуальна оцінка після перезимівлі в полі [4]; біологічний метод контролю: застосування монолітів [5], у висівних ящиках [6], поліетиленових стаканчиках (без дна) [7] та ін. Проте за умов змін клімату та теплих м'яких зим проведення оцінки в польових умовах стало неможливим.

Механізми стійкості in vitro досліджують із використанням проліферуючих клітинних культур. Культури клітин злаків широко отримуються [8]. Клітинні культури пшениці одержують як із незрілих зародків, так i сегментів проростків [9]. У процесі вирощування первинні експлантати можуть давати різні відповіді на культуру in vitro: пряме проростання, каллусогенез, різні типи 
морфогенезу. Швидкість цих реакцій різна. Вони можуть здійснюватися паралельно або почергово. Зрозуміло, що першими відбуваються реакції без зміни морфології такі, як пряме проростання. Причиною всіх цих подій є фізіолого-біохімічні особливості тканин (навіть окремих їхніх ділянок) рослини [10]. Тому, залежно від кінцевої мети, використовують широкий спектр живильних середовищ, що суттєво впливає/змінює на тип реакції взаємодії генотип/середовище $(\mathrm{G} / \mathrm{E})$.

Такий перебіг подій характеризує життєздатний організм, клітини якого адекватно реагують на зміни умов культивування. Звичайно, під час вирощування спостерігають i небажані феноменології: уповільнення (відсутність) реакції 3 боку первинного експлантату із подальшою його елімінацією. Такі факти можуть бути наслідками патологічних процесів на рівні тканин рослини. Зрозуміло, що масштаб порушень є вирішальною обставиною.

Не виключено, що регенеровані рослини, які піддавали проморожуванню на стадії зернівки, індукували механізми, кооперовані 3 особливостями відновлення in vivo. Якщо це було б, то ці особливості могли певним чином відобразитися на реакціях клітинних культур, оскільки зумовлені метаболізмом. Отже, можливо припустити, що 3'являються передумови для оцінки віддалених наслідків впливу низьких температур, які зазвичай не враховуються.

Метою підходу стало отримання клітинних культур пшениці озимої 3 генотипів, які піддавали процедурі проморожування, а також установлення ефективності поєднання методів дослідження in vivo та in vitro під час оцінки показників життєздатності тканин.

\section{Матеріали й методи}

Дослідження проводили впродовж 20152017 pр. Об'єктом дослідження були різні генотипи пшениці озимої та ярої, отримані в Інституті фізіології рослин і генетики НАН України. Для активації механізмів стійкості застосовано вдосконалений метод проморожування в накільченому насінні [11]. Загартування й проморожування матеріалу здійснювали в камерах КН-1M. Зернівки замочували у звичайній воді до розтріскування насіннєвої оболонки та загартовували в режимі температур від $\mathrm{t}^{0} 0^{0}$ до $\mathrm{t}^{0}-8^{0}$ (зі зниженням на $2^{0}$ через кожні дві доби). Після цієї процедури температуру знижували ( 2 \%год) до досягнення параметру $\mathrm{t}^{0}-20^{0}$, після чого насіння проморожували впродовж 24 годин. У подальшому проморожені зерна ділили на дві групи. Одну витримували в лабораторних умовах за $\mathrm{t}^{0} 15-20^{0} \mathrm{C}$. Це виступало експресмаркером збереження життєздатності рослинного організму, показником реалізації неспецифічних адаптаційних реакцій генотипу. Другу групу переносили для природної перезимівлі в польові умови (дослідне сільськогосподарське виробництво Інституту фізіології рослин і генетики НАН України, смт Глеваха, Васильківський р-н, Київська обл.). Таким чином створювалася можливість скринінгу внеску ознаки морозостійкості в загальну зимостійкість окремої рослини в масиві стійких/нестійких генотипів. Отже, проходив перший етап оцінювання in vivo.

Життєздатні варіанти відновлювалися. Після формування колосу in vivo iз них виділяли окремі зернівки на стадії незрілих зародків. Зернівки стерилізували, виділяли незрілі зародки, котрі в асептичних умовах переносили на живильні середовища різного складу для визначення оптимальних умов [12; 13$]$. Оцінювали реакції первинних експлантатів на умови in vitro. Контролем слугували генотипи, які розвивалися без попереднього проморожування.

Для оптимізації одержання культур клітин пшениці використовували низку оригінальних середовищ та їх модифікації. Для культивування генотипів пшениці найбільш придатним виявилося живильне середовище В5 Гамборга [14], на якому не відбувалося масової елімінації первинних експлантатів i водночас спостерігали переважання реакцій дедиференціації.

Результати, наведені в таблицях, є статистично обробленими середніми показниками за вказані роки.

\section{Результати та обговорення}

Пророщування генотипів пшениці озимої після проморожування в лабораторних умовах (експрес-тестування), а також регенерація рослин in vivo показали, що варіанти суттєво вирізнялися за рівнем стійкості. Це проявлялося у відсутності/зниженні інтенсивності проростання. Для оцінки життєздатності регенерованих рослин незрілі зародки виділяли 3 нормально вегетуючих екземплярів.

У табл. 1 наведено характеристики реакцій контрольних (без проморожування, тільки перезимівля) генотипів на культивування 
Реакції незрілих зародків пшениці на культивування in vitro

\begin{tabular}{|c|c|c|c|c|}
\hline \multirow{2}{*}{$\begin{array}{c}\text { Генотип } \\
\text { пшениці }\end{array}$} & \multicolumn{4}{|c|}{ Живильне середовище В5 Гамборга } \\
\cline { 2 - 5 } & 1 & 2 & 3 & 4 \\
\hline Золотоколоса & ++ & ++ & ++ & Не відзначали \\
\hline Володарка & ++ & ++ & ++ & Не відзначали \\
\hline Смуглянка & Не проходило & +++ & +++ & Не відзначали \\
\hline
\end{tabular}

Примітка. Типи реакиій: 1 - пряме проростання; 2 - проростання/каллусогенез; 3 -каллусогенез; 4 - елімінація; ступінь прояву реакції (\%): + - менше $30 \%$; ++ - 30-50\%; +++ - більше $50 \%$.

експлантатів на середовищі В5. Початок проліферації відзначали на 5-7 доби культивування. Початковий пасаж тривав 30 діб. Фіксували всі можливі напрями розвитку первинного експлантату: пряме проростання, каллусогенез, поєднання обох подій.

Відсутність елімінації у всіх генотипів може свідчити на користь життєздатності паренхіматичних клітин рослини in vivo. Водночас простежено реалізацію генотипових особливостей якісного та кількісного характеру. На наше переконання, таким чином проявляється неоднорідний характер тканин первинного експлантату, який у подальшому може бути джерелом сомаклональної мінливості [8].

Рослини, які проморожували, також формували клітинні культури. Загалом такі варіанти in vivo відзначались уповільненим темпом розвитку. Ця особливість зберігалась і в поведінці первинних експлантатів при перенесенні в систему in vitro. У цьому випадку також спостерігали різні події, зумовлені взаємодією G/E. Водночас різний тип реакцій, на нашу думку, не дає адекватної оцінки морозостійкості, оскільки в подальшому темп розвитку таких культур не відрізнявся від росту клітинних культур контролю. Точний аналіз ступеня життєздатності тканин первинного експлантату проявлявся за умов, що викликали пряме проростання (живильне середовище F1 [15]). Для прямого проростання не потрібно суттєвих змін біохімічного статусу клітин. In vitro проходить процес, аналогічний проростанню зернівки in vivo. У табл. 2 наведено показники ефективності проростання незрілих зародків. Спостерігаємо суттєву різницю між генотипами, котрі проморожувались, а також між ними та варіантами без проморожування.

Оскільки тестувалися генотипи пшениці озимої, то отримані дані викликають особливу зацікавленість.

Видно, що навіть за відсутності проморожування значна кількість $(<60 \%)$ зародків не проросла, що може свідчити на користь нежиттєздатності (малої життєздатності) тканин експлантату, які не активувалися навіть за сприятливих умов in vitro. Проморожування створювало додатковий стрес, стійкість до якого проявилась у варіантів при тестуванні.

Зрозуміло, що регенерація рослин in vivo не розкриває повного потенціалу генотипу, оскільки наявні та подальші зовнішні фактори можуть суттєво впливати на всі інтегральні показники, у тому числі продуктивність. Водночас проростання зародків in vitro може вказувати на оптимальний фізіологічний стан об'єкта. У разі його детального аналізу стає доступним установлення внесків окремих складових метаболізму.

Генотипи пшениці озимої варіювали за рівнем стійкості. Очевидно, що виключення процедури проморожування збільшувало кількість потенційно (помірно) стійких варіантів. 3 іншого боку, проморожування (без подальшого тестування в системі in vitro) не давало можливості точного встановлення параметрів стійкості. Ці факти суттєво подовжують процес селекції. Водночас проморожування in vivo $\mathrm{y}$ поєднанні 3 подальшим тестуванням in vitro може прискорити процес відбору стійких варіантів.

Ефективність проростання незрілих зародків пшениці in vitro

\begin{tabular}{|c|c|}
\hline Генотип пшениці & Кількість пророслих експлантатів, \% \\
\hline Генот. 12101; проморожування & $31,0 \pm 2,3$ \\
\hline Генот. 12100; проморожування & $12,0 \pm 1,4$ \\
\hline Контроль; без проморожування & $63,0 \pm 4,2$ \\
\hline
\end{tabular}


Отже, у ході проведених досліджень установлено: 1 - генотипи пшениці озимої можуть варіювати за рівнем морозостійкості; 2 - установленню рівня морозостійкості сприяє поєднання методів проморожування in vivo 3 подальшим дослідженням поведінки клітинних культур in vitro. Створюється можливість оцінки фізіологічного стану рослини per se; 3 поєднання методів in vivo та in vitro може бути новим напрямом біотехнології пришвидшеного відбору морозостійких рослин пшениці.

\section{Література}

1. Терлецкая, Н. В. Неспецифические реакичи зерновых злаков на абиотические стрессы in vivo $u$ in vitro; Алматы, 2012, 208 с.

2. Колючий, В. Т; Власенко, В. А.; Борсук, Г. Ю. Селекиія, насінництвво і технологї вирощування зернових колосових культур $у$ Лicocmeny Украӥни, Аграрна наука: Київ; 2007, с 226-258.

3. Хоменко, Л. О.; Кочмарський, В. С. Досвід Миронівського інституту пшениці ім. В. М. Ремесла НААН 3 визначення морозо- та зимостійкості пшениці м'якої озимої. Матеріали Х Всеукраїнської науково-практичної конферениії молодих вчених $i$ спеціалістів, 20-21 березня 2014 р. Кіровоград, c 104-107.

4. Рябчун, Н. І. Зимостійкість озимої пшениці та методи ї̈ оичнки при селекиії нових сортів: збірник наукових пращь СГІ. Одеса, 2004, 6, с 68-75.

5. Личикаки, В. М. Перезимовка озимых культур. Колос, Москва, 1974, 205 с.

6. Кириченко, В. В.; Петренкова, В. П.; Рябчун, Н. І.; Ткачик, С. О.; Андрющенко, А. В. Пшениця озима. Метод визначення морозостійкості сортів: ДСТУ 4749, 2007 Держспожсивстандарт України; Київ, 2008, 8 с.
7. Патент на корисну модель МПК' Н04 G 7//00 С 1//00. Спосіб оцінювання $i$ добору морозостійких форм озимих зернових культур Хоменко, Л. О.; Шередеко, Л. М.; Кочмарський, В. С.; Яременко, Р. В.; Ткалич, В. В. №38732, заявлено 15.05.2008; 2009 бюлетень №1.

8. Larkin, P. J.; Scowcroft, W. R. Somaclonal variation in crop improvement. See Ref; 1982, 21, p 289-314.

9. Рахимбаев, И. Р.; Тивари, Ш.; Бишимбаева, Н. К.; Кушнаренко, С. В.; Азимова, Е. Д. Биотехнология зерновых культур; Гылым: АлмаАта, 1992, 240 c.

10. Кушнаренко, С. В. Морфогенез и регенерация в культуре тканей пшеницы. Автореферат дис. канд. биол. наук, Душанбе, 1990. $22 \mathrm{c}$.

11. Демідов, О. А.; Кочмарський, В. С.; Кириленко, В. В.; Булавка, Н. В.; Коломієць, Л. А.; Гуменюк, О. В.; Хоменко, Л. О.; Юрченко, Т. В.; Дергачов, О. Л. Способи добору селекційного матеріалу пшениці м'якої озимої (Triticum aestivum L.), Миронівка, 2016, 20 с.

12. Волощук, Г.Д. Суспензійна культура пшениці Triticum aestivum L. та іiі використання в генетико-селекційних дослідженнях. Автореф. дис. канд. біол. наук, Київ, 2000. 20 с.

13. Heyser, J. W.; Nabors, M. W.; MacKinnon, C. Dykes T. A.; Demott, K. J.; Kautzman, D. C.; MujeebKazi, A. Long-term, high-frequency plant regeneration and the induction of somatic embryogenesis in callus cultures of wheat (Triticum aestivum L.) Z. Pflanzenzüchtg; 1985, 94, p 21-233.

14. Gamborg, J. L.; Miller, R. A.; Ojima, K. Nutrient requirement of suspension cultures of soybean roots. Exp. Cell Res; 1968, 50, p 151-158.

15. Green, C. E.; Phillips, R. L. Plant regeneration from tissue cultures of maize. Crop Sci. 1975, 15, p 417-421. 